\title{
IgG Subclass Variation of a Monoclonal Antibody Binding to Human Fc-Gamma Receptors
}

\author{
Rekha Patel, Krista K. Johnson \\ Bruce A. Andrien and Paul P. Tamburini
}

Alexion Pharmaceuticals Inc, 352 Knotter Dr, Cheshire, CT 06410, USA

Received 2012-01-06, Revised 2013-07-02; Accepted 2013-07-17

\begin{abstract}
The importance of human $\mathrm{Fc}$ receptors in immune regulation is well known. Their role is critical not only in the recruitment of cellular effector functions but also in regulating the balance in the periphery between autoimmunity and tolerance. Despite their central importance, there is a dearth of literature on controlled numeric comparisons in affinities of antibody subclasses for gamma receptors. To date, no studies have directly compared humanized antibodies with the same variable region and differing $\mathrm{Fc}$ region subclasses which would rule out any differences that may be attributed to variations in the variable region. In this study we characterized the interaction between four humanized monoclonal antibodies; $\mathrm{IgG}_{1}, \mathrm{G}_{2}, \mathrm{G}_{3}$ and $\mathrm{G}_{4}$, each possessing an identical variable region and the repertoire of human Fc-gamma (Fc $\gamma$ ) receptors (Fc $\gamma R$ I, Fc $\gamma$ RIIA, Fc $\gamma R I I B$, Fc $\gamma$ RIIIA and Fc $\gamma$ RIIIB). The studies were performed using both Surface Plasmon Resonance (SPR) and Enzyme-Linked ImmunosorbentAssay (ELISA) formats. The affinities of the antibodies for their antigen molecule, an endogenous human protein, were also analyzed by SPR. While the identity of the Fc-region had no significant effect on the binding to antigen, substantially different affinities for each of the Fc $\gamma$ receptors, Fc $\gamma$ RI, Fc $\gamma$ RIIA, Fc $\gamma$ RIIB, Fc $\gamma$ RIIIA and Fc $\gamma$ RIIIB were observed across the various Fc-subclasses.
\end{abstract}

Keywords:FC-Gamma Receptors, Surface Plasmon Resonance (SPR), Monoclonal Antibodies, IgG Subclass, Affinity, ELISA

\section{INTRODUCTION}

Monoclonal Antibodies (mAbs) are a rapidly growing class of highly specific therapeutics (Stockwin and Holmes 2003; Piggee 2008; Carter 2006) which, over the last three decades, have become effective treatments for immunological, oncological, transplantation, cardiovascular and infectious diseases (Nissim and Chernajovsky, 2008; Zhang et al., 2007). Currently there are more than 20 FDA approved antibody therapeutics on the market, all of which are of the Immunoglobulin $\mathrm{G}$ ( $\mathrm{IgG}$ ) class. An $\mathrm{IgG}$ is comprised of two light chains each consisting of variable and constant domains and two heavy chains, each consisting of one variable and 3 constant domains. The two heavy chains are linked to each other and to a light chain each by disulfide bonds.

Through advancements in engineering know-how, biopharmaceutically desired characteristics such as affinity, avidity, half-life and effector functions of an antibody can be manipulated (Hudson and Souriau, 2003; Chowdhury and $\mathrm{Wu}$ 2005; Stavenhagen et al., 2007; Horton et al., 2008; Zalevsky et al., 2009). For example, a triple mutation (M252Y/S254T/T256E) inserted into the $\mathrm{C}_{\mathrm{H}} 2$ domain of a human $\mathrm{IgG}$ molecule increased its binding by approximately 10 -fold to the human neonatal receptor FcRn with almost a 4-fold increase in serum half-life (Oganesyan et al., 2009)

Corresponding Author: Rekha Patel, Alexion Pharmaceuticals Inc, 352 Knotter Dr, Cheshire, CT 06410, USA Tel: 2032718280 Fax: 2032716436 
while other changes in the Fc domain of IgG have yielded a greater than 100-fold improvement in Antibody-Dependent Cellular Cytotoxicity (ADCC) (Stavenhagen et al., 2007). Many of the approved therapeutic $m A$ bs are of the $\operatorname{IgG}_{1}$ subclass, reviewed by Carter (2006). Advantages of $\mathrm{IgG}_{1}$ include a characteristic longer half-life and the ability to orchestrate immune mediated effector functions (Natsume et al., 2009; Strome et al., 2007).

$\mathrm{IgG} \mathrm{Fc}$ receptors play an important role in the control of effector functions of mAbs (Sisto et al., 2009) including ADCC (Fanger et al., 1989), complement activation, phagocytosis (Anderson et al., 1990), release of inflammatory mediators (Anegon et al., 1998), antibody production (Fridman, 1993) and immune complex clearance. Three functionally and structurally distinct types of $\mathrm{Fc} \gamma$-Receptors $(\mathrm{Fc} \gamma \mathrm{R})$ are expressed on human leukocytes, namely: Fc $\gamma$ RI (CD64), Fc $\gamma$ RII (CD32) and FcyRIII (CD16). The latter two classes are

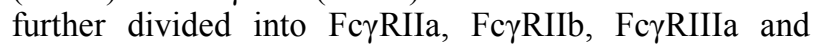
Fc $\gamma$ RIIIb. All Fc $\gamma$ Rs belong to the immunoglobulin superfamily and differ in their antibody affinities. Fc $\gamma$ RI has a higher affinity for $\operatorname{IgG}\left(\mathrm{K}_{\mathrm{a}}=10^{8}-10^{9} \mathrm{M}^{-1}\right)$, than Fc $\gamma$ RII $\left(\mathrm{K}_{\mathrm{a}}<10^{7} \mathrm{M}^{-1}\right)$ or Fc $\gamma$ RIII $\left(\mathrm{K}_{\mathrm{a}}<3 \times 10^{7} \mathrm{M}^{-1}\right)$ reviewed by Gessner et al., (1998). Fc $\gamma \mathrm{RI}$ has three immunoglobulin domains in the extracellular portion whereas FcyRII and FcyRIII have two. It is this third domain of Fc $\gamma$ RI which confers high affinity and the ability to bind monomeric IgG (Gessner et al., 1998; Allen and Seed 1989). In contrast, the lower affinities of Fc $\gamma$ RII and Fc $\gamma$ RIII for IgG renders these receptors suited to activation through the avidity afforded by the association with multimeric immune complexes (Shields et al., 2001). Ligation of Fc $\gamma$ Rs produces activating signals as with Fc $\gamma$ RI and Fc $\gamma$ RIII, or inhibitory signals as with FcyRIIb, both of which are integral to a balanced immune response (Nimmerjahn and Ravetch, 2005). FcyRs bind to the lower hinge region of $\mathrm{IgG}$ and in the case of $\mathrm{IgG}_{1}$, a common set of residues appears to be involved in the binding to all Fc $\gamma$ Rs (Sautes et al., 2003; Shields et al., 2001).

While the various subclasses of IgGs have distinct selectivity profiles for the $\mathrm{Fc} \gamma$ receptor repertoire (Salfield 2007; Presta et al., 2002), most of the supporting studies feature qualitative rankings of Fc $\gamma \mathrm{Rs}$ functional association (Strome et al., 2007; Nimmerjahn and Ravetch 2005; Sorge et al., 2003). Few studies have shown comprehensive numerical affinities for antibody subclasses binding to the human Fc $\gamma$ Rs. One study has reported binding of $\operatorname{IgG}_{1}$ with RIIa, RIIb and RIII only (Maenaka et al., 2001). Another study by Bruhns et al. (2009) discussed the specificity and affinity of Fc $\gamma$ Rs and their polymorphic variants to different human $\operatorname{IgG}$ subclasses, using purchased chimeric monoclonal and polyclonal antibodies. However, no studies to date have compared human antibodies with the same variable region in combination with the differing Fc subclasses.

Obtaining accurate affinities of each subclass for various FcyRs and understanding the importance of immune complex clearance is important in the design of antibody-based therapeutics. For example, this can allow monoclonal antibodies to be specifically engineered to manipulate clearance. In this study four recombinant antibodies each possessing an identical variable region and differing only in the subclass of Fc-region $\left(\mathrm{G}_{1}, \mathrm{G}_{2}, \mathrm{G}_{3}\right.$ and $\left.\mathrm{G}_{4}\right)$ were produced and shown to be structurally and functionally indistinguishable with respect to the variable region and interaction with the antigen protein. These antibodies were evaluated for binding to each of the Fc $\gamma$ Rs: Fc $\gamma$ RI, Fc $\gamma$ RIIA, Fc $\gamma$ RIIB, Fc $\gamma$ RIIIA and FcrRIIIB using both a monovalent binding SPR format and a multivalent ELISA.

\section{MATERIALS AND METHODS}

\subsection{Antibody and Protein Reagents}

Human Fc gamma receptors were purchased from $\mathrm{R}$ and D systems; (Cat\# Fc $\gamma$ RI-1257-FC, Fc $\gamma$ RIIA-1330CD, Fc $\gamma$ RIIB-1875-CD, Fc $\gamma$ RIIIA-4325-FC and Fc $\gamma$ RIIIB-1597-FC/CF). Anti-Fc (goat anti-human-Fc IgG antibody, $1 \mathrm{mg} \mathrm{mL} \mathrm{m}^{-1}$ ) was obtained from KPL (Cat\#01-10-20). The endogenous human protein antigen was obtained from commercial sources.

\subsection{Generation of Purified mAbs}

Monoclonal antibodies to the endogenous human protein antigen containing either $G_{1}, G_{2}, G_{3}$ or $G_{4}$ constant regions and the same variable domain were generated using standard molecular biology methods. Plasmids were transfected into $\mathrm{CHO} \mathrm{K} 1$ cells and cell lines established using single cell cloning (CHO-GS used under license from Lonza Biologics plc.). Antibodies were purified from cell culture supernatants using protein A affinity chromatography. The structural differences between each of the mAb subclasses are well known (Wypych et al., 2008) and include the number of disulfide bonds in the hinge region, the location of the heavy and light chain disulfide bonds and the approximately $5 \%$ overall primary sequence divergence between the Fc-regions. 


\subsection{IEF}

Purified antibodies (10 $\mu \mathrm{g}$ each) were run on a $\mathrm{pH} 3-10$ Invitrogen IEF gel (Cat\#EC6655BOX) and calibrated with an IEF $\mathrm{pH}$ 3-10 Invitrogen Serva marker kit (Cat\#39212-01). Gels were stained with Coomassie brilliant blue R-250 (Research Organics Cat\#1447C).

\subsection{Electrospray ToF}

The monoclonal antibodies were injected into an Agilent 1100 HPLC and the LC effluent electrosprayed into the Agilent LC/MSD ESI-ToF mass spectrometer operated in positive ion mode. A Vydac $\mathrm{C} 4$ reverse phase column $(1.0 \times 250 \mathrm{~mm}, 5 \mu \mathrm{m}$ particles, $300 \AA$ pore size) was used with a mobile phase A of $94.9 \%$ Water, 5\% Acetonitrile, $0.1 \%$ Trifluoroacetic Acid (TFA) and mobile phase B of $79.9 \%$ Acetonitrile, $20 \%$ Water, $0.1 \%$ TFA. An LC-MS run time of 35 min. was used with a 1 min ballistic desalting gradient from $20-100 \%$ B 1 min post injection. MS data were generated with Mass Hunter acquisition software and processed using Mass Hunter Qualitative with BioConfirm deconvolution software to resolve the charge state envelope for each sample and to determine the mass of the intact antibody and any variant structures present. The calibration check spectra were acquired pre-acquisition and postacquisition of the samples, using ES-ToF Tuning mix.

\subsection{Biacore Analysis}

Kinetic data were obtained by surface plasmon resonance performed on a Biacore 3000 biosensor (Biacore AB, Uppsala, Sweden). The CM5 sensor chips (research grade), amine coupling reagents (NHS, EDC, ethanolamine $\mathrm{pH} 8.5$, HBS-EP buffer, $10 \mathrm{mM}$ sodium acetate buffer ( $\mathrm{pH}$ 5.0) and P20 were obtained from Biacore AB. The binding kinetics of mAbs to the antigen was determined by a capture approach using single cycle kinetics (Karlsson et al., 2006). In this approach, the CM5 sensor chip was normalized and primed using fresh degassed/filtered HBS-EP buffer prior to anti-Fc mAb immobilization at $25^{\circ} \mathrm{C}$ on two flow cells of the chip at a concentration of $0.1 \mathrm{mg} \mathrm{mL}^{-1}$ in $10 \mathrm{mM}$ sodium acetate pH 5.0 for $8 \mathrm{~min}$. at $10 \mu \mathrm{L} \mathrm{min}{ }^{-1}$ via amide coupling chemistry. The mAbs were diluted between 0.8 and 1.4 $\mu \mathrm{g} \mathrm{mL} \mathrm{m}^{-1}$ and, in separate experiments, injected as follows: $\mathrm{IgG}_{1}-20 \mu \mathrm{L}, \mathrm{IgG}_{2}-30 \mu \mathrm{L}, \mathrm{IgG}_{3}-18 \mu \mathrm{L}, \mathrm{IgG}_{4}-20$ $\mu \mathrm{L}$ at $20 \mu \mathrm{L} \mathrm{min}{ }^{-1}$. Concentrations of $0.375,0.75,1.5,3$ and $6 \mathrm{nM}$ antigen in HBS-EP were injected over the Anti-FC/mAb surface in single cycle kinetics mode. Experiments were run at $25^{\circ} \mathrm{C}$ sensor surface temperature. Data were analyzed using a titration kinetics 1:1 Model in BIAsimulation software (Biacore AB, Uppsala, Sweden). The binding affinities of the
mAbs to Fc $\gamma$ receptors (Fc $\gamma$ RI, Fc $\gamma$ RIIA, Fc $\gamma$ RIIB, Fc $\gamma$ RIIIA and Fc $\gamma$ RIIIB) were determined by directly immobilizing the mAbs to the sensor surface. The mAbs diluted in $10 \mathrm{mM}$ sodium acetate $\mathrm{pH} 5$ were immobilized to one flow cell; the other flow cell was immobilized as a blank reference. Immobilization levels were optimized to show sufficient binding levels of receptors. Various concentrations of receptors were analyzed in HBS-EP. Experiments were run either by single cycle kinetics mode or steady state equilibrium depending on initial affinities in experimental scouting. Data were analyzed using a Steady State Affinity Model in BIAsimulation software (Biacore AB, Uppsala, Sweden). Table 1 outlines concentrations of antibody used in immobilization (including resonance units immobilized), receptor concentration and experimental mode.

\begin{tabular}{|c|c|c|c|c|}
\hline FcyR & $\begin{array}{l}\text { mAb Concn } \\
. \mu \mathrm{g} / \mathrm{mL}\end{array}$ & $\begin{array}{l}\text { RU's mAb } \\
\text { Immobilized }\end{array}$ & $\begin{array}{l}\text { Fc } \gamma \mathrm{R} \\
\text { Concentrations (nM) }\end{array}$ & $\begin{array}{l}\text { Expt } \\
\text { Mode }\end{array}$ \\
\hline Anti-) & 0.8 & 318 & $0.19,0.38,0$. & \\
\hline $\mathrm{Fc}_{(\mathrm{G} 1}$ & & & $75,1.5,3.0$ & $\mathrm{SCK}^{\mathrm{a}}$ \\
\hline Anti-) & 62 & 1570 & $31,63,125,250$, & \\
\hline $\begin{array}{l}\mathrm{Fc}_{(\mathrm{G} 2} \\
\text { Anti- }\end{array}$ & 0.1 & 318 & $\begin{array}{l}500,1000,2000 \\
0.19,0.38,0 .\end{array}$ & $\mathrm{SSE}^{\mathrm{b}}$ \\
\hline $\mathrm{Fc}_{(\mathrm{G} 3)}$ & & & $75,1.5,3.0$ & $\mathrm{SCK}^{\mathrm{a}}$ \\
\hline $\begin{array}{l}\text { Anti- } \\
\text { Fc }(\text { G4) } \\
\text { Fc } \gamma \text { RIIA }\end{array}$ & 0.7 & 338 & $\begin{array}{l}0.19,0.38 \\
0.75,1.5,3.0\end{array}$ & $\mathrm{SCK}^{\mathrm{a}}$ \\
\hline Anti- & 1.6 & 542 & $24,49,98,195$, & \\
\hline $\begin{array}{l}\mathrm{Fc}_{(\mathrm{G} 1)} \\
\text { Anti- } \\
\mathrm{Fc}_{(\mathrm{G} 2)}\end{array}$ & 62 & 1569 & $\begin{array}{l}391,781,1563,3125 \\
24,49,98,195, \\
391,781,1563,3125\end{array}$ & $\begin{array}{l}\mathrm{SSE}^{0} \\
\mathrm{SSE}^{\mathrm{b}}\end{array}$ \\
\hline $\begin{array}{l}\text { Anti- } \\
\mathrm{Fc}_{(\mathrm{G} 3)}\end{array}$ & 2.1 & 547 & $\begin{array}{l}24,49,98,195,391, \\
781,1563,3125\end{array}$ & $\mathrm{SSE}^{\mathrm{b}}$ \\
\hline $\begin{array}{l}\text { Anti- } \\
\text { Fc }_{(\mathrm{G} 4)} \\
\text { Fe } \boldsymbol{\text { r RIIB }}\end{array}$ & 1.4 & 546 & $\begin{array}{l}24,49,98,195,391, \\
781,1563,3125\end{array}$ & $\mathrm{SSE}^{\mathrm{b}}$ \\
\hline $\begin{array}{l}\text { Anti- } \\
\text { Fc }_{(\mathrm{G} 1)}\end{array}$ & 81.1 & 2584 & $\begin{array}{l}26,52,104,208, \\
417,833,1667, \\
3333,6666\end{array}$ & $\mathrm{SSE}^{\mathrm{b}}$ \\
\hline $\begin{array}{l}\text { Anti- } \\
\mathrm{Fc}_{(\mathrm{G} 2)}\end{array}$ & 62 & 1569 & $\begin{array}{l}26,52,104,208,417 \\
833,1667,3333,6666\end{array}$ & $\mathrm{SSE}^{\mathrm{b}}$ \\
\hline $\begin{array}{l}\text { Anti- } \\
\text { Fc }_{(\mathrm{G} 3)}\end{array}$ & 2.1 & 542 & $\begin{array}{l}26,52,104,208,417, \\
833,1667,3333\end{array}$ & $\mathrm{SSE}^{\mathrm{b}}$ \\
\hline $\begin{array}{l}\text { Anti- } \\
\text { Fc }_{(G 4)} \\
\text { Fc } \gamma \text { RIIIA }\end{array}$ & 1.4 & 546 & $\begin{array}{l}26,52,104,208,417, \\
833,1667,3333\end{array}$ & $\mathrm{SSE}^{\mathrm{b}}$ \\
\hline $\begin{array}{l}\text { Anti- } \\
\mathrm{Fc}_{(\mathrm{G} 1)}\end{array}$ & 1.6 & 524 & $\begin{array}{l}9,17,34,69,139,278, \\
556,1111,2222,4444\end{array}$ & $\mathrm{SSE}^{\mathrm{b}}$ \\
\hline $\begin{array}{l}\text { Anti- } \\
\mathrm{Fc}_{(\mathrm{G} 2)}\end{array}$ & 62 & 1569 & $\begin{array}{l}9,17,34,69,139,278, \\
556,1111,2222\end{array}$ & $\mathrm{SSE}^{\mathrm{b}}$ \\
\hline $\begin{array}{l}\text { Anti- } \\
\mathrm{Fc}_{(\mathrm{G} 3)}\end{array}$ & 2.1 & 547 & $\begin{array}{l}9,17,34,69,139,278, \\
556,1111,2222\end{array}$ & $\mathrm{SSE}^{\mathrm{b}}$ \\
\hline $\begin{array}{l}\text { Anti- } \\
\text { Fc }_{(G 4)} \\
\text { FcyRIIIB }\end{array}$ & 1.4 & 546 & $\begin{array}{l}9,17,34,69,139,278 \\
, 556,1111,2222,4444\end{array}$ & $\mathrm{SSE}^{\mathrm{b}}$ \\
\hline $\begin{array}{l}\text { Anti- } \\
\mathrm{Fc}_{(\mathrm{G} 1)}\end{array}$ & 1.6 & 542 & $\begin{array}{l}16,31,63,125,250, \\
500,100,2000\end{array}$ & $\mathrm{SSE}^{\mathrm{b}}$ \\
\hline $\begin{array}{l}\text { Anti- } \\
\mathrm{Fc}_{(\mathrm{G} 2)}\end{array}$ & 62 & 18171 & $\begin{array}{l}16,31,63,125,250, \\
500,100,2000\end{array}$ & $\mathrm{SSE}^{\mathrm{b}}$ \\
\hline $\begin{array}{l}\text { Anti- } \\
\mathrm{Fc}_{(\mathrm{G} 3)}\end{array}$ & 2.1 & 546 & $\begin{array}{l}16,31,63,125,250 \\
500,100,2000\end{array}$ & $\mathrm{SSE}^{\mathrm{b}}$ \\
\hline $\begin{array}{l}\text { Anti- } \\
\mathrm{Fc}_{(\mathrm{G} 4)}\end{array}$ & 137 & 16098 & $\begin{array}{l}16,31,63,125,250, \\
500,100,2000\end{array}$ & $\mathrm{SSE}^{\mathrm{b}}$ \\
\hline
\end{tabular}




\subsection{Binding of Antibodies to FcyR by ELISA}

Ni-NTA pre-coated plates (Qiagen, Cat\#35061) were incubated with $50 \mu \mathrm{L}$ well ${ }^{-1}$ of His-tagged human Fc $\gamma \mathrm{R}$ I, IIb/c or III ( $\mathrm{R}$ and D systems Cat\#s1257-FC, 1875-CD, 4325-FC) at a receptor concentration of $5 \mu \mathrm{g}$ $\mathrm{mL}^{-1}$ in PBS, overnight at $4^{\circ} \mathrm{C}$. Following overnight incubation with receptor, the plates were washed 3 times with PBS buffer containing $0.02 \%$ Tween-20 using a multiwash advantage plate washer. After washing, $50 \mu \mathrm{L}$ of complexed antibodies were diluted in PBS buffer containing $0.05 \%$ Tween- 20 and incubated in the plate for $60 \mathrm{~min}$. at room temperature. Complexed antibody was prepared by prior incubation of antibodies overnight with a biotinylated $\mathrm{F}(\mathrm{ab})_{2}$ fraction of goat-anti-human $\mathrm{F}\left(\mathrm{ab}^{\prime}\right)_{2}$ (Jackson Immunolabs Cat\# 109-066-006), at a 2:1 antibody: $\mathrm{F}\left(\mathrm{ab}^{\prime}\right)_{2}$ molar ratio in PBS. Following incubation of the plate wells with complexed antibody, the plates were washed as described above and followed by the addition of $50 \mu \mathrm{L}$ well ${ }^{-1}$ of the secondary antibody streptavidin-HRP to detect biotinylated complexed antibodies (Zymed Cat\#43-4323, diluted $1 / 2000$ in PBS buffer containing $0.05 \%$ Tween-20). Incubation with secondary antibody was for $60 \mathrm{~min}$. at room temperature. Following this incubation, wells were washed and color development initiated with 100 $\mu \mathrm{L}$ well ${ }^{-1}$ of $o$-phenylenediamine dihydrochloride (OPD,
Sigma Cat\# P 9187). Reactions were stopped with $25 \mu \mathrm{L}$ well $^{-1} 12.5 \% \mathrm{H}_{2} \mathrm{SO}_{4}$ and the absorbance read at $490 \mathrm{~nm}$.

\section{RESULTS}

\subsection{Physical and Structural Characterization of Recombinantly Expressed Monoclonal Antibody Subclass Variants}

IEF analysis of the antibodies used in this study is shown in Fig. 1, from which the following pI values were obtained: $\operatorname{IgG}_{1}=7.9 ; \operatorname{IgG}_{2}=7.1 ; \operatorname{IgG}_{3}=8.0 ; \operatorname{IgG}_{4}=$ 6.7. The appearance of multiple bands most likely reflects heterogeneity in post translational modifications. The electrospray ToF evaluation revealed a considerable difference in the molecular weight of the various subclasses in accordance with differences in the amino acid sequence and number of disulfide bonds (Fig. 2). The experimentally determined molecular weights were: $\operatorname{IgG}_{1}=148,475( \pm 17 \mathrm{ppm})$; $\operatorname{IgG}_{2}=147,982( \pm 24 \mathrm{ppm}) ; \operatorname{IgG}_{3}=158,668( \pm 21 \mathrm{ppm}) ;$ $\mathrm{IgG}_{4}=148,025( \pm 21 \mathrm{ppm})$, with error calculated from a theoretically determined mass. The higher molecular weight of $\mathrm{IgG}_{3}$ compared to the other IgG subclasses is attributed to the elongated hinge region.

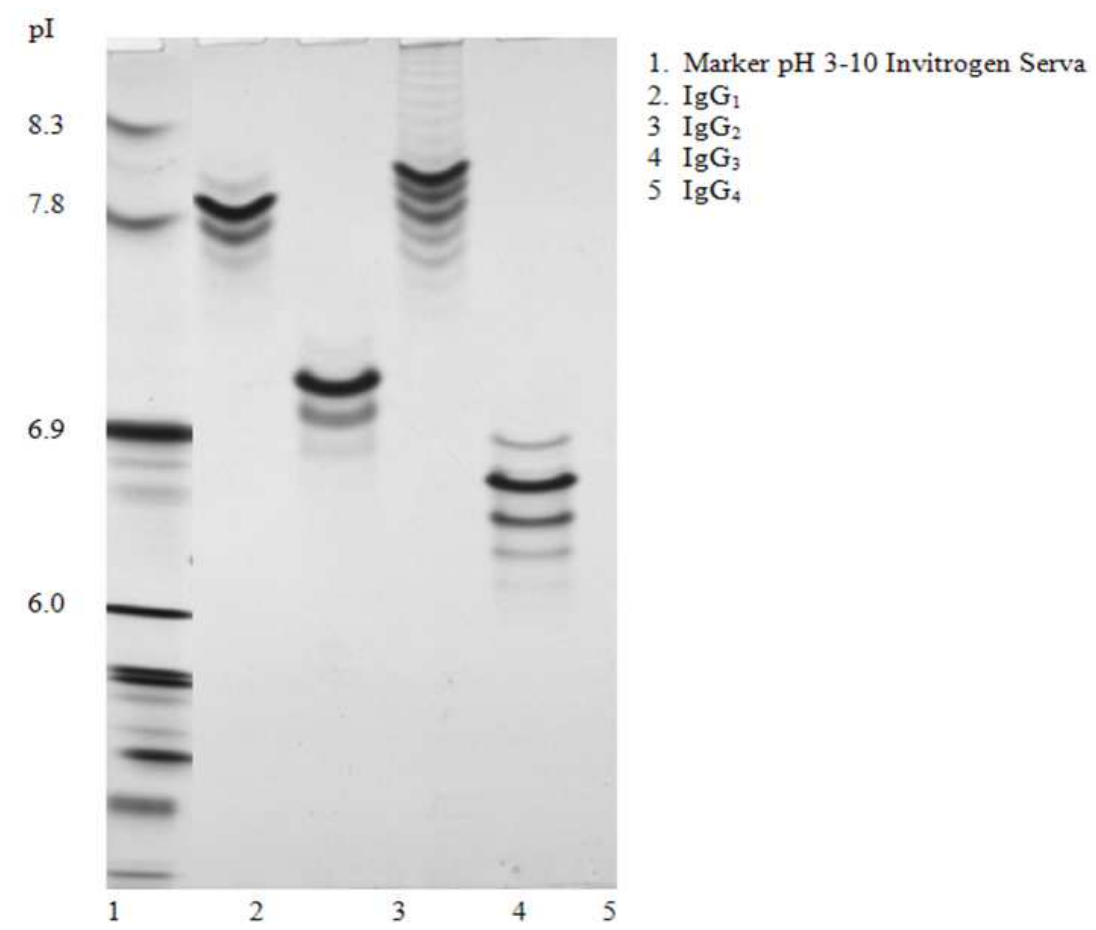

Fig. 1. The heterogeneity of mAb subclasses is shown by vertical IEF. The following pI values were 
Rekha Patel et al. / American Journal of Biochemistry and Biotechnology 9 (3): 206-218, 2013
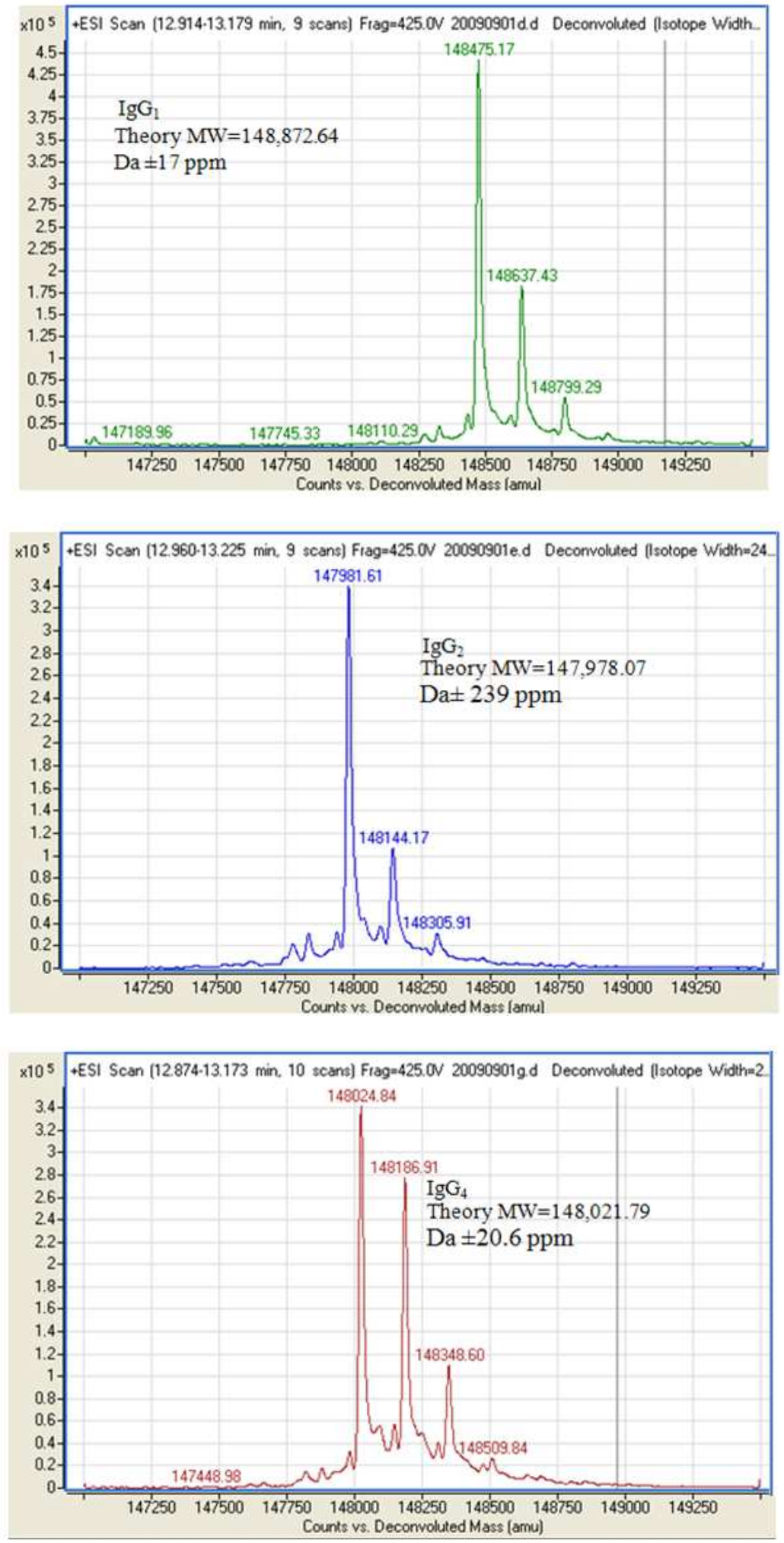
Rekha Patel et al. / American Journal of Biochemistry and Biotechnology 9 (3): 206-218, 2013

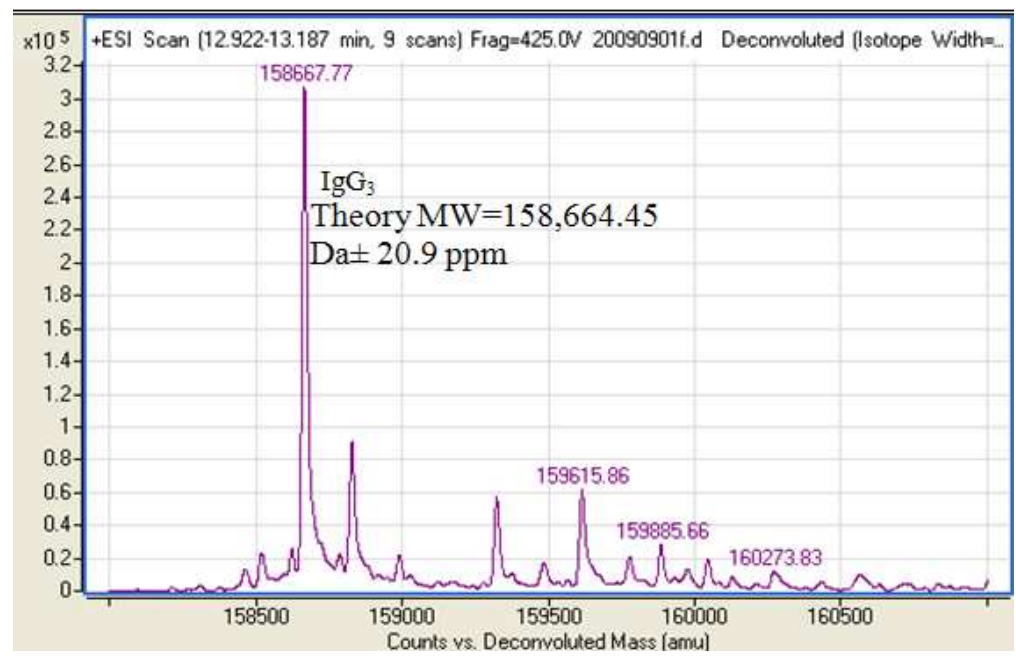

Fig. 2. Intact molecular weights of each of the IgG subclasses evaluated by Electrospray ToF. The experimentally determined molecular weights were: $\operatorname{IgG}_{1}=148,475$ ( \pm 17 ppm); $\operatorname{IgG}_{2}=147,982\left( \pm 24\right.$ ppm); $\operatorname{IgG}_{3}=158,668\left( \pm 21\right.$ ppm); $\operatorname{IgG}_{4}=148,025$ ( \pm 21 ppm)
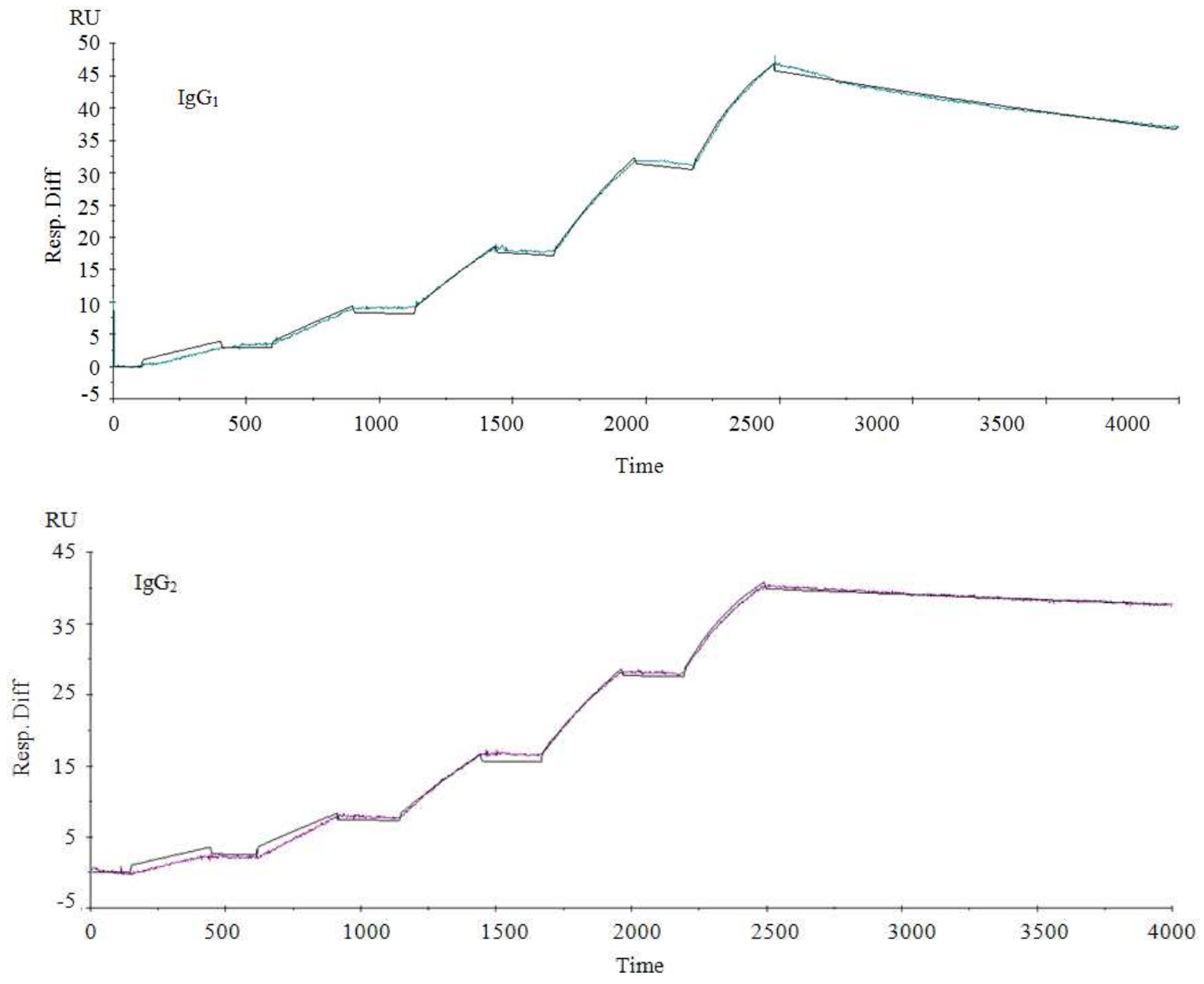
Rekha Patel et al. / American Journal of Biochemistry and Biotechnology 9 (3): 206-218, 2013
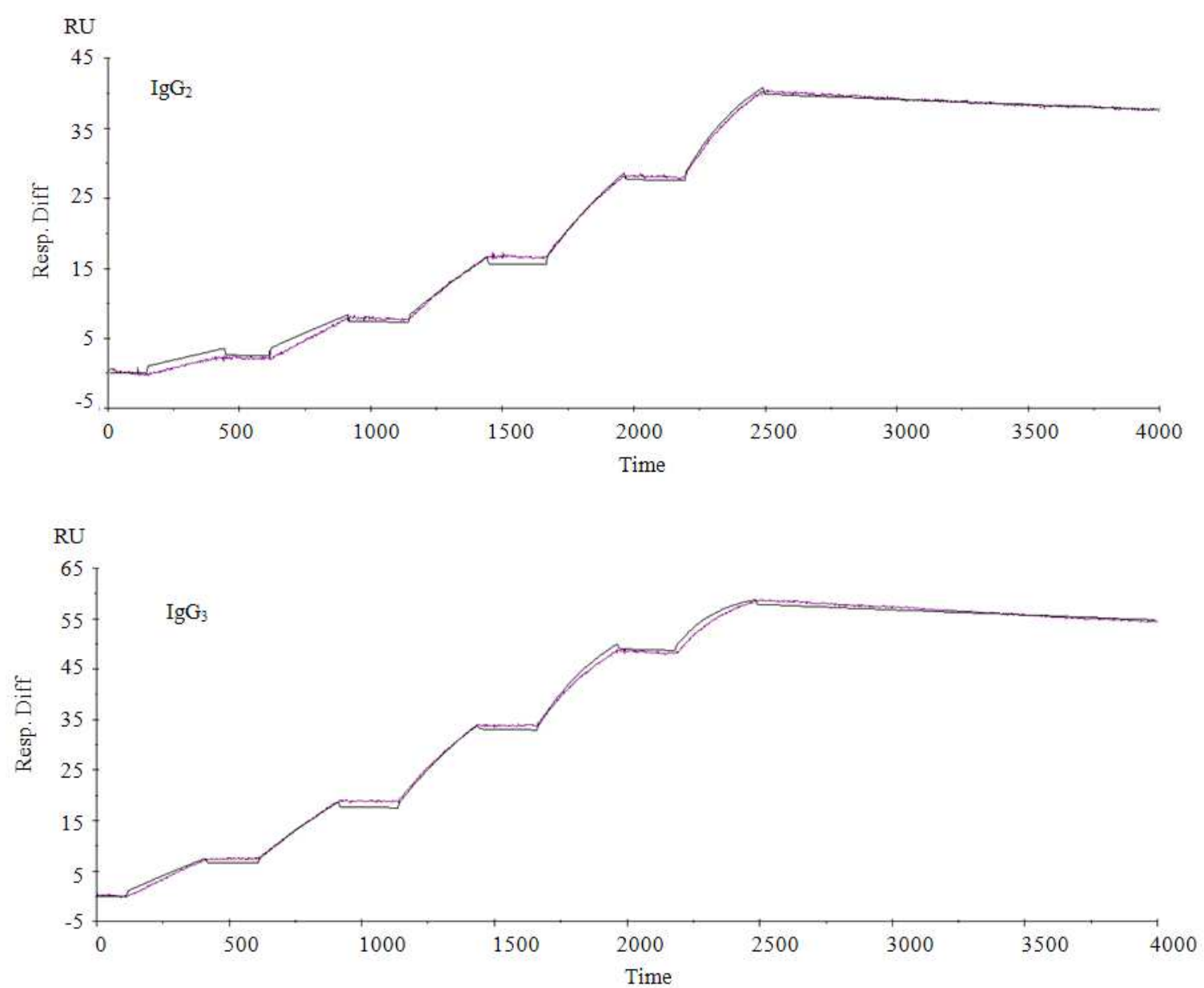

Fig. 3. Sensorgrams of $m A b$ subclasses $\left(G_{1}, G_{2}, G_{3}\right.$ and $\left.G_{4}\right)$ binding to antigen using a single cycle kinetics technique by Biacore. Each step in the sensorgram represents increasing concentration of antigen. The final concentration/step shows both association and dissociation of antibody binding to antigen

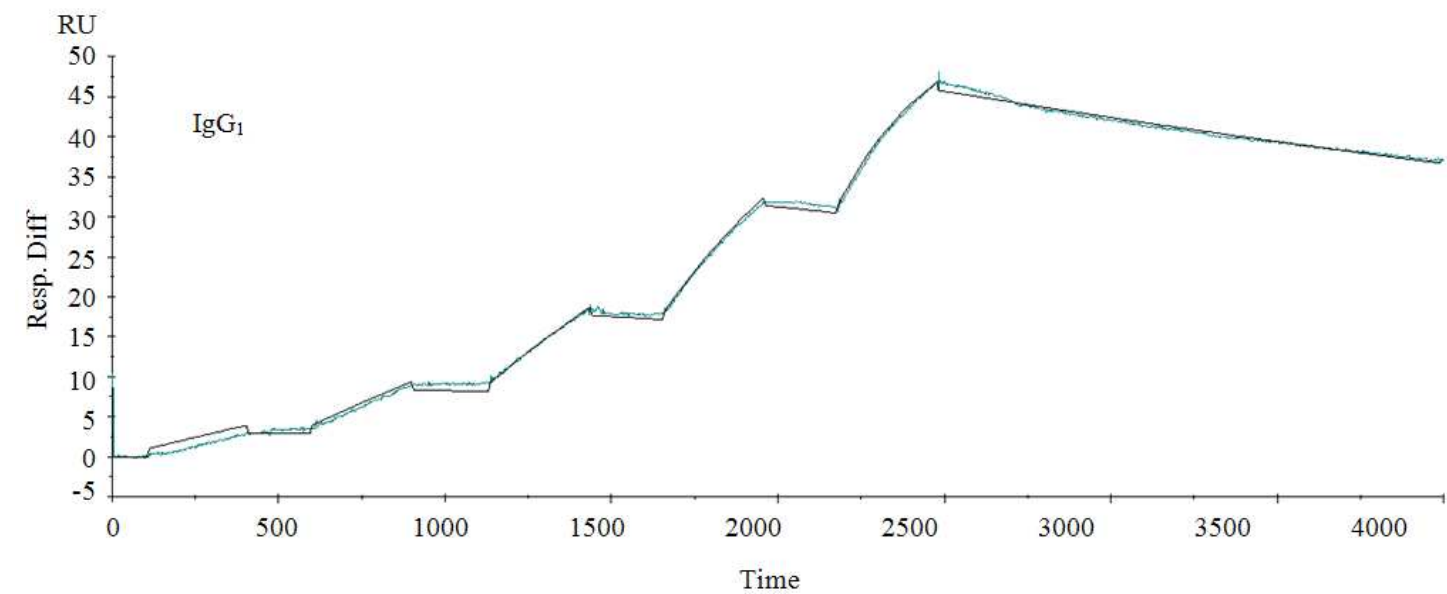


Rekha Patel et al. / American Journal of Biochemistry and Biotechnology 9 (3): 206-218, 2013
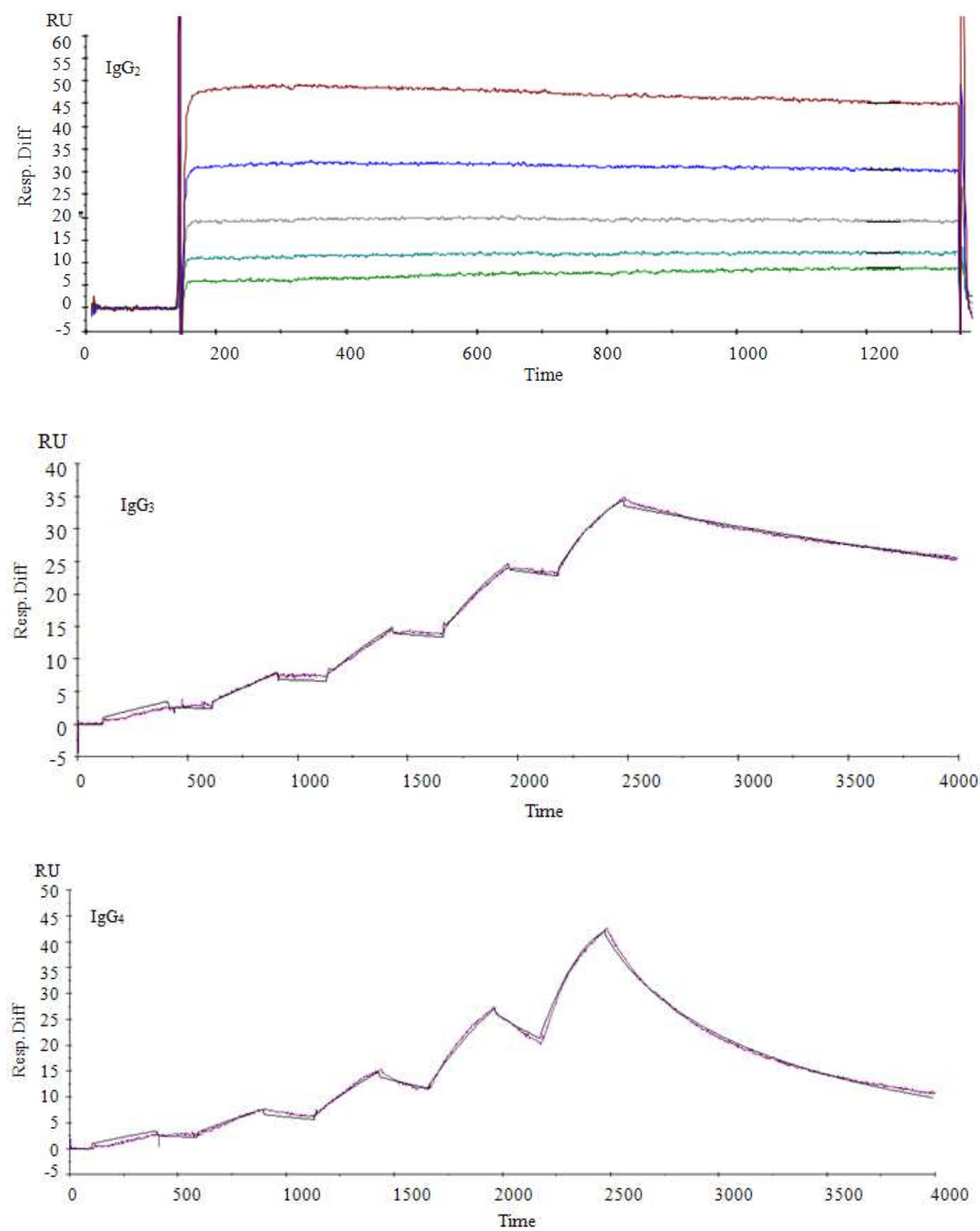

Fig. 4. Sensorgrams of $m A b$ subclasses $\left(G_{1}, G_{2}, G_{3}\right.$ and $\left.G_{4}\right)$ binding to Fc $\gamma$ RI receptor by Biacore. $m A b$ subclasses $\left(G_{1}, G_{3}\right.$ and $\left.G_{4}\right)$ binding to Fc $\gamma R I$ evaluated by single cycle kinetics. Each step represents increasing concentration of Fc $\gamma$ RI. The final step/concentration shows both association and dissociation of the antibody binding to Fc $\gamma \mathrm{RI}$. IgG $\mathrm{Ig}_{2}$ was evaluated by steady state eqilibrium. Each step represents increasing concentration of Fc $\gamma$ RI Receptor 
Rekha Patel et al. / American Journal of Biochemistry and Biotechnology 9 (3): 206-218, 2013
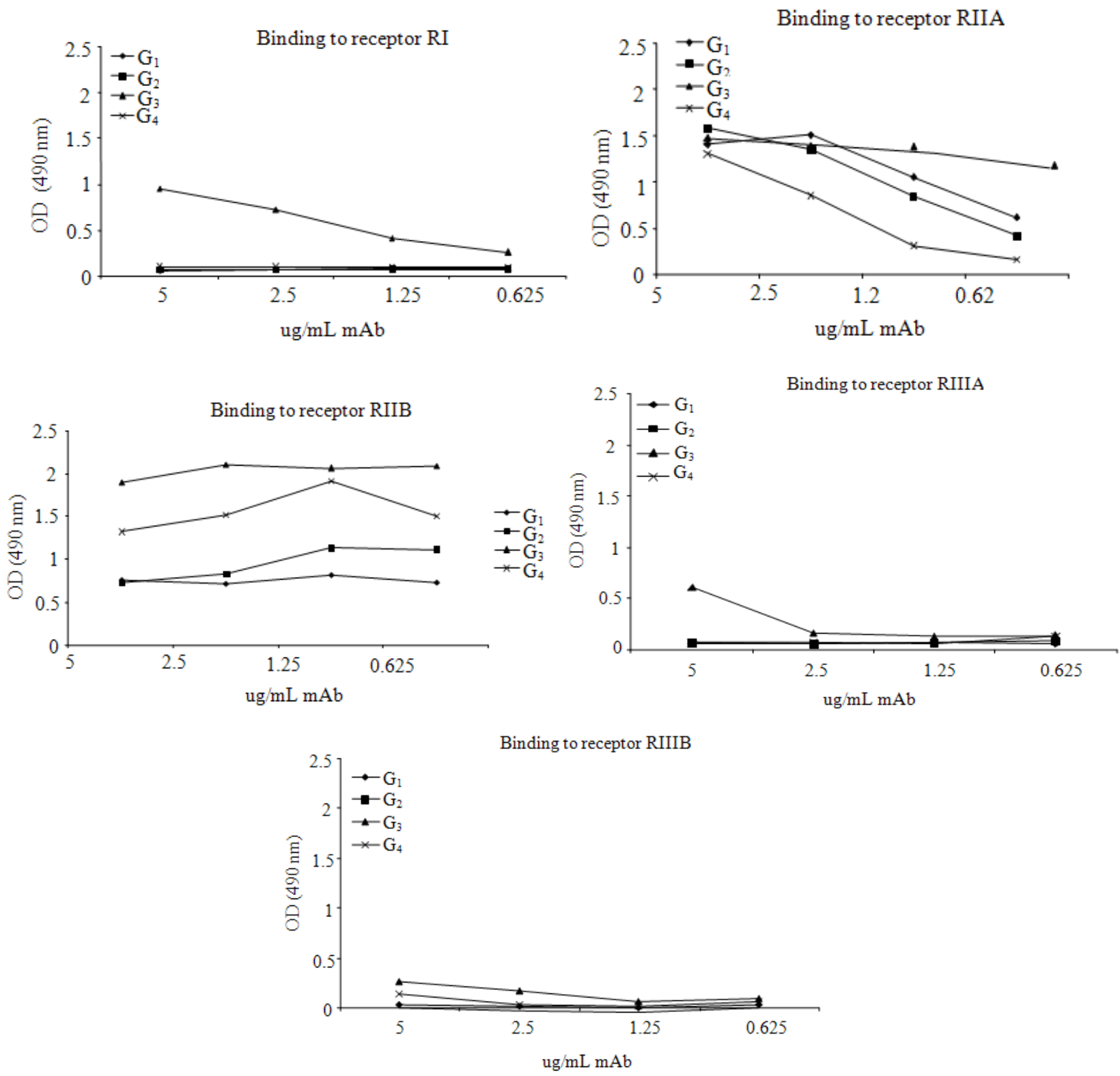

Fig. 5. Binding of cross linked humanized antibody subclasses $\left(\mathrm{G}_{1}, \mathrm{G}_{2}, \mathrm{G}_{3}\right.$ and $\mathrm{G}_{4}$ to various $\mathrm{F} c \gamma$ Receptors as immune complexes with $\mathrm{F}(\mathrm{ab})_{2}$-anti-F(ab') $)_{2}$, using an ELISA format. All IgG subtypes bind well to Fc $\gamma$ RIIA and Fc $\gamma$ RIIB, the inhibitory Fc $\gamma R$. $\mathrm{IgG}_{3}$ binds to all Fc $\gamma \mathrm{Rs}$

Table 2. Kinetics of $m A b s\left(G_{1}, G_{2}, G_{3}\right.$ and $\left.G_{4}\right)$ binding to antigen by Biacore

\begin{tabular}{llll}
\hline $\mathrm{mAb}_{\text {Subclass }}$ & $\mathrm{k}_{\mathrm{a}}\left(\mathrm{M}^{-1} \mathrm{~s}^{-1}\right)$ & $\mathrm{k}_{\mathrm{d}}\left(\mathrm{s}^{-1}\right)$ & $\mathrm{K}_{\mathrm{D}}(\mathrm{M})$ \\
\hline $\mathrm{IgG}_{1}$ & $6.91 \mathrm{E}+05$ & $2.62 \mathrm{E}-05$ & $3.80 \mathrm{E}-11$ \\
$\mathrm{IgG}_{2}$ & $6.82 \mathrm{E}+05$ & $4.01 \mathrm{E}-05$ & $5.88 \mathrm{E}-11$ \\
$\mathrm{IgG}_{3}$ & $1.05 \mathrm{E}+06$ & $3.63 \mathrm{E}-05$ & $3.45 \mathrm{E}-11$ \\
$\mathrm{IgG}_{4}$ & $6.94 \mathrm{E}+05$ & $2.81 \mathrm{E}-05$ & $4.04 \mathrm{E}-11$ \\
\hline
\end{tabular}

Table 3. Binding affinities of mAbs with different Fc regions to human Fc-gamma receptors by Biacore

\begin{tabular}{|c|c|c|c|c|c|}
\hline $\begin{array}{l}\mathrm{mAb} \\
\text { subclass }\end{array}$ & $\begin{array}{l}\text { Receptor } \\
\text { Fc } \gamma \text { RI } \\
K_{D}(M)\end{array}$ & $\begin{array}{l}\text { Receptor } \\
\text { Fc } \gamma \text { RIIA } \\
\mathrm{K}_{\mathrm{D}}(\mathrm{M})\end{array}$ & $\begin{array}{l}\text { Receptor } \\
\text { Fc } \gamma R I I B \\
\mathrm{~K}_{\mathrm{D}}(\mathrm{M})\end{array}$ & $\begin{array}{l}\text { Receptor } \\
\text { Fc } \gamma \text { RIIIA } \\
\mathrm{K}_{\mathrm{D}}(\mathrm{M})\end{array}$ & $\begin{array}{l}\text { Receptor } \\
\text { Fc } \gamma \text { RIIIB } \\
\mathrm{K}_{\mathrm{D}}(\mathrm{M})\end{array}$ \\
\hline$\overline{\mathrm{IgG}_{1}}$ & $1.23 \mathrm{E}-10$ & $8.00 \mathrm{E}-07$ & $3.10 \mathrm{E}-06$ & $8.50 \mathrm{E}-07$ & $1.90 \mathrm{E}-06$ \\
\hline $\mathrm{IgG}_{2}$ & $1.40 \mathrm{E}-06$ & $3.78 \mathrm{E}-07$ & $6.80 \mathrm{E}-06$ & $2.20 \mathrm{E}-06$ & $\mathrm{ND}^{\mathrm{a}}$ \\
\hline $\mathrm{IgG}_{3}$ & $7.90 \mathrm{E}-11$ & $8.97 \mathrm{E}-08$ & $1.30 \mathrm{E}-06$ & $3.90 \mathrm{E}-07$ & $1.44 \mathrm{E}-06$ \\
\hline $\mathrm{IgG}_{4}$ & $6.90 \mathrm{E}-10$ & $6.00 \mathrm{E}-07$ & $1.70 \mathrm{E}-06$ & $3.46 \mathrm{E}-06$ & $4.60 \mathrm{E}-06$ \\
\hline
\end{tabular}


Table 4. Affinity ranking for the binding of mAbs with varying Fc regions to Fc-gamma receptors as determined by Biacore and an ELISA format

\begin{tabular}{|c|c|c|}
\hline $\begin{array}{l}\text { Fc-receptor } \\
\text { type }\end{array}$ & $\begin{array}{l}\text { Rank order } \\
\text { by SPR }\end{array}$ & $\begin{array}{l}\text { Rank order } \\
\text { by ELISA }\end{array}$ \\
\hline Fc $\gamma R I$ & $\operatorname{IgG}_{2}<<\operatorname{IgG}_{4}<\operatorname{IgG}_{1}<\operatorname{IgG}_{3}$ & $\mathrm{IgG}_{3}$ \\
\hline $\mathrm{Fc} \gamma$ & $\mathrm{IgG}_{1} \sim \operatorname{IgG}_{4}<<\operatorname{IgG}_{2}<\operatorname{IgG}_{3}$ & $\operatorname{IgG}_{4}<\operatorname{IgG}_{2}$ \\
\hline RIIA & & $<\operatorname{lgG}_{1}<\operatorname{IgG}_{3}$ \\
\hline $\mathrm{Fc} \gamma$ & $\mathrm{IgG}_{1} \sim \operatorname{IgG}_{2} \sim \operatorname{IgG}_{3} \sim \operatorname{IgG}_{4}$ & $\operatorname{IgG}_{1} \sim$ \\
\hline RIIB & & $\mathrm{IgG}_{2} \sim \mathrm{IgG}_{3} \sim \mathrm{IgG}_{4}$ \\
\hline $\mathrm{Fc} \gamma$ & $\mathrm{IgG}_{2} \sim \operatorname{IgG}_{4}<\operatorname{IgG}_{1}<\mathrm{IgG}_{3}$ & $\mathrm{IgG}_{3}$ \\
\hline RIIIA & & (bound poorly) \\
\hline $\mathrm{Fc} \gamma$ & $\mathrm{IgG}_{1} \sim \operatorname{IgG}_{2} \sim \operatorname{IgG}_{3} \sim \operatorname{IgG}_{4}$ & $\mathrm{IgG}_{4}<\mathrm{IgG}_{3}$ \\
\hline RIIIB & & (both bound poorly) \\
\hline
\end{tabular}

\subsection{Binding of the Monoclonal Antibody Subclass Variants to the Antigen Protein}

The sensorgrams from single cycle kinetics are shown in Fig. 3. All four subclass variant antibodies bound with high affinity to the endogenous human protein antigen. Negligible difference was observed in $\mathrm{K}_{\mathrm{D}}$ values among the variants (Table 2). The observed $\mathrm{K}_{\mathrm{D}}$ values were: $\operatorname{IgG}_{1}=38 \mathrm{pM}, \mathrm{IgG}_{2}=59 \mathrm{pM}, \operatorname{IgG}_{3}=35$ $\mathrm{pM}, \mathrm{IgG}_{4}=40 \mathrm{pM}$ (Table 2). The association $\left(\mathrm{k}_{\mathrm{a}}\right)$ and dissociation $\left(\mathrm{k}_{\mathrm{d}}\right)$ rate constants were also similar. These data clearly show that changes in the Fc type do not result in conformational changes in the variable region that affect antigen protein binding.

\subsection{Affinity of Binding of the Monoclonal Antibody Subclass Variants to Fc $\gamma R$ :}

The binding affinities of the four subclass variant antibodies to each of Fc $\gamma$ RI, Fc $\gamma$ RIIA (R131), Fc $\gamma$ RIIB, Fc $\gamma$ RIIIA (V158) and FcyRIIIB as determined by SPR were significantly different (Table 3). As an example the sensorgrams of Fc $\gamma R$ I binding to each $\mathrm{mAb}$ are shown in Fig. 4 and the affinity rankings derived from all of the single cycle kinetics and steady state equilibrium experiments for all mAbs binding to each of the gamma receptors are summarized in Table 4. With the exception of $\mathrm{IgG}_{2}$, the subclass variants had the strongest affinity for Fc $\gamma$ RI with the following $\mathrm{K}_{\mathrm{D}}$ values: $\mathrm{IgG}_{1}=123 \mathrm{pM}$, $\mathrm{IgG}_{3}=79 \mathrm{pM}, \mathrm{IgG}_{4}=690 \mathrm{pM} . \mathrm{IgG}_{2}$ had the strongest affinity for Receptor Fc $\gamma$ RIIA (378nM). $\operatorname{IgG}_{3}$ had comparatively high affinity for Fc $\gamma \operatorname{RIIA}\left(\mathrm{K}_{\mathrm{D}}=90 \mathrm{nM}\right)$ and Fc $\gamma$ RIIIA $\left(K_{D}=390 \mathrm{nM}\right)$. The binding affinities for all other receptor-antibody binding combinations were in the much weaker micromolar range.

\subsection{Avidity driven Binding of the Monoclonal Antibody Subclass Variants to F $\gamma \gamma R$}

Multivalent immune complexes were generated by cross linking each $\mathrm{mAb}$ with a $\mathrm{F}\left(\mathrm{ab}{ }^{\prime}\right)_{2}$ fraction of goatanti-human $\mathrm{F}(\mathrm{ab})_{2}$. The avidity of the complexed $\mathrm{mAbs}$ for binding to each surface immobilized FcR was determined by ELISA (Fig. 5). The complexed mAbs were all able to bind to Fc $\gamma$ RIIB, the inhibitory receptor, whereas FcyRI only bound $\mathrm{IgG}_{3}$. Fc $\gamma$ RIIA bound all subclasses, with $\mathrm{G}_{3}>\mathrm{G}_{1}>\mathrm{G}_{2}>\mathrm{G}_{4}$. Fc $\gamma$ RIIIB showed minimal binding to $\operatorname{IgG}_{3}$, (Table 4).

\section{DISCUSSION}

These studies are the first to evaluate FcyR binding to all IgG subclasses using functional humanized $\mathrm{mAbs}$ with identical variable regions. Several other studies have evaluated the binding of particular subclasses to some of these receptors including a study by Maenaka et al. (2001) where the binding of Fc $\gamma$ receptors RIIA, RIIB and RIII to $\mathrm{IgG}_{1}$ was evaluated. Bruhns et al., (2009) undertook a comprehensive assessment of the relationship between $\mathrm{mAb}$ subclass and binding to FcRs that also incorporated the consideration of receptor polymorphism, but the study used mouse/human chimeric monoclonal and polyclonal antibodies.

Monovalent binding of $\mathrm{Fc}$ receptors and the mAbs, as measured by SPR, indicated affinities for Fc $\gamma R I$ in the high $p M$ range with $G_{3}$ having the highest affinity, followed by $G_{1}$. These affinities were stronger than those observed by Canfield and Morrison (1991) and Gessner et al. (1998) although the same rank order was observed in each case. Interaction of monovalent antibodies of each subclass with the low affinity Fc $\gamma$ RII and Fc $\gamma$ RIII receptors, which normally rely on multivalent complexing, were measurable by SPR in our study with $\mathrm{G}_{3}$ having the strongest affinity for Fc $\gamma$ RIIA and Fc $\gamma$ RIIIA $\left(\mathrm{K}_{\mathrm{D}}\right.$ of 89 and 390nM, respectively). This was consistent with Bruhns et al., (2009) concerning low affinity Fc $\gamma$ RIIIA bound by monomeric $G_{3}$. Each of the four subclasses of $m A b$ bound to Fc $\gamma$ RI, Fc $\gamma$ RIIA, Fc $\gamma$ RIIB and Fc $\gamma$ RIIIA as determined by SPR. Fc $\gamma$ RIIIB, which did not appear to bind to $\mathrm{IgG}_{2}$ in either monovalent format or multivalent format, was the only exception.

Our study also showed $\operatorname{IgG}_{1}$ bound human FcyR with affinities $\left(\mathrm{K}_{\mathrm{D}}\right)$ ranging from $\mathrm{pM}$ in the case of 
Fc $\gamma$ RI (123pM) and Fc $\gamma$ RIIA (800nM) to $\mu \mathrm{M}$ as seen with Fc $\gamma$ RIIB, Fc $\gamma$ RIIIA and FcyRIIIB (all close to 1 $\mu \mathrm{M})$. The $\mathrm{IgG}_{2}$ monoclonal antibody also bound $\mathrm{Fc} \gamma \mathrm{R}$ with a narrower range than that seen for $\operatorname{IgG}_{1}$. Most of the affinities were in the single digit micromolar range, with the exception of FcrRIIA which had an affinity of $0.38 \mu \mathrm{M}$ and FcrRIIIB, which was not determined. $\mathrm{IgG}_{3}$ was able to bind all Fc $\gamma \mathrm{R}$ 's, with a very broad range of affinities. The strongest affinity was for Fc $\gamma R I$, with a $K_{D}$ of $79 p M$. As with $I g G_{1}, I g G_{3}$ had nanomolar affinity for Fc $\gamma$ RIIA (90nM). Low affinity receptors Fc $\gamma$ RIIB, Fc $\gamma$ RIIIA and Fc $\gamma$ RIIIB had $K_{D}$ values in the low micromolar range. $\mathrm{IgG}_{4}$ exhibited a similar pattern of affinities for all FcyR, with $\mathrm{K}_{\mathrm{D}}$ values of $690 \mathrm{pM}$ for $\mathrm{Fc} \gamma \mathrm{RI}, 600 \mathrm{nM}$ for Fc $\gamma$ RIIA and values in the low micromolar range for low affinity receptors Fc $\gamma$ RIIB, Fc $\gamma$ RIIIA and Fc $\gamma$ RIIIB.

Overall, SPR assessment of monovalent interactions between humanized $\operatorname{IgG}$ and $\mathrm{Fc} \gamma \mathrm{R}$ support published studies by Bruhns et al. (2009) in which Fc $\gamma$ RI has strong affinity for $\operatorname{IgG}_{1}, G_{3}$ and $G_{4}$ subtypes, with $\mathrm{K}_{\mathrm{D}}$ values in the picomolar range. Fc $\gamma$ RIIA has moderate affinity for all subtypes, including $\mathrm{IgG}_{2}$, with $\mathrm{K}_{\mathrm{D}}$ values in the nanomolar range. The remaining $\mathrm{Fc} \gamma \mathrm{Rs}$ which were evaluated (Fc $\gamma$ RIIB, Fc $\gamma$ RIIIA and Fc $\gamma$ RIIIB) had affinities in the micromolar range.

Fc $\gamma$ RIIB, Fc $\gamma$ RIIIA and Fc $\gamma$ RIIIB, as well as Fc $\gamma$ RIIA are considered low affinity receptors and exert their regulatory functions in a multivalent format, via immune complexing. Affinity rankings of the humanized monoclonal antibodies, in immune complexes with $\mathrm{F}(\mathrm{ab}){ }_{2}{ }_{2}$-anti-F(ab)' ${ }_{2}$, are compared with monomeric SPR derived affinities in Table 4.

In this avidity driven format, $\operatorname{IgG}_{1}$ and $\mathrm{IgG}_{2}$ bound to Fc $\gamma$ RIIA and Fc $\gamma$ RIIB, the inhibitory Fc $\gamma$ R. $\mathrm{IgG}_{3}$ showed association with all FcyRs and was the only subtype which associated with Fc $\gamma$ RI and Fc $\gamma$ RIIIA. Rank order of $\mathrm{IgG}_{3}$ and $\mathrm{Fc} \gamma \mathrm{Rs}$ show that the strongest affinity is for Fc $\gamma$ RIIA followed by Fc $\gamma$ RIIB $>$ Fc $\gamma$ RI $>$ Fc $\gamma$ RIIIA $>$ Fc $\gamma$ RIIIB. $\operatorname{IgG}_{4}$ had no affinity for Fc $\gamma$ RI or FcyRIIIA and only marginal association with Fc $\gamma$ RIIIB. It did associate strongly with Fc $\gamma$ RIIA and Fc $\gamma$ RIIB, the inhibitory receptors.

Low affinity, inhibitory receptors, FcyRIIB and Fc $\gamma$ RIIA, bound all $\mathrm{mAb}$ subclasses, with $\mathrm{IgG}_{3}$ having a greater binding than $\mathrm{IgG}_{1}$ in both monomeric and multimeric formats. This is in agreement with Bruhns et al. (2009) who also examined interactions both in monomeric and multimeric conditions. The low affinity receptor FcyRIIIA had discernible binding to all IgG subtypes, with $K_{D}$ values in the micromolar range as determined by SPR. Using similar SPR studies; Bruhns et al. (2009) reported affinities for Fc $\gamma$ RIIIA with only $\operatorname{IgG}_{1}$ and $\operatorname{IgG}_{2}$. In our study using SPR, FcyRIIIB was found to have a weak affinity for $\mathrm{IgG}_{1}, \mathrm{IgG}_{3}$ and $\mathrm{IgG}_{4}$. No affinity was seen for $\mathrm{IgG}_{1}$ or $\mathrm{IgG}_{2}$ with Fc $\gamma$ RIIIB using multimeric ELISA.

\section{CONCLUSION}

This study evaluated the interaction of four subclass variant antibodies both to the antigen protein and to the repertoire of human FcyRs. Comparable affinities with $K_{D}$ values ranging between 35 and 59 pM were observed for the binding of all four antibodies to the antigen, showing that the differing Fc regions did not impart conformational changes to the variable region associated with altered antigen protein binding. In contrast, the subclass variants exhibited significantly different affinities for each of the Fc $\gamma$ receptors Fc $\gamma$ RI, Fc $\gamma$ RIIA, Fc $\gamma$ RIIB, Fc $\gamma$ RIIIA and Fc $\gamma$ RIIIB. Since the subclass variants each had the exact same VH, VL and CL regions the differences seen were attributable solely to the $\mathrm{Fc}$ regions known to be involved in FcrR binding.

\section{ACKNOWLEDGEMENT}

The authors thank Michelle Giannoni for plasmid construction and Jeffrey Hunter and Patricia Bento for cell line work.

\section{REFERENCES}

Allen, J.M. and B. Seed, 1989. Isolation and expression of functional high-affinity $\mathrm{Fc}$ receptor complementary DNAs. Science, 243: 378-381. PMID: 2911749

Anderson, C.L., L. Shen, D.M. Eicher, M.D. Wewers and J.K. Gill, 1990. Phagocytosis mediated by three distinct $\mathrm{Fc}$ gamma receptor classes on human leukocytes. J. Expt. Med., 171: 1333-1345. DOI: 10.1084/jem.171.4.1333 
Anegon, I., M.C. Cuturi, G. Trinchieri and B. Perussia, 1998. Interaction of FC receptor (CD16) ligands induces transcription of interleukin 2 receptor (CD25) and lymphokine genes and expression of their products in human natural killer cells. J. Expt. Med., 167: 452-472. DOI: 10.1084/jem.167.2.452

Bruhns, P., B. Iannascoli, P. England, D.A. Mancardi and N. Fernandez et al., 2009. Specificity and affinity of human Fcgamma receptors and their polymorphic variants for human $\mathrm{IgG}$ subclasses. Blood, 113: 3716-3725. PMID: 19018092

Canfield, S.M. and S.L. Morrison, 1991. The binding affinity of human $\mathrm{IgG}$ for its high affinity FC receptor is determined by multiple amino acids in the $\mathrm{CH} 2$ domain and is modulated by the hinge region. J. Exp. Med., 173: 1483-1491.

Carter, P.J., 2006. Potent antibody therapeutics by design. Nat. Rev. Immunol., 6: 343-357. DOI: 10.1038/nri1837

Chowdhury, P.S. and H. Wu, 2005. Tailor-made antibody therapeutics. Methods, 36: 11-24. DOI: 10.1016/j.ymeth.2005.01.002

Fanger, M.W., R.F. Graziano, L. Shen and P.M. Guyre, 1989. FC gamma $\mathrm{R}$ in cytotoxicity exerted by mononuclear cells. Chem. Immunol., 47: 214-253. PMID: 2532893

Fridman, W.H., 1993. Regulation of B-cell activation and antigen presentation by FC receptors. Curr. Opin. Immunol., 5: 355-360. DOI: 10.1016/09527915(93)90053-U

Gessner, J.E., H. Heiken, A. Tamm and R.E. Schmidt, 1998. The IgG Fc receptor family. Ann. Hematol., 76: 231-248. DOI: 10.1007/s002770050396

Horton, H.M., M.J. Bernett, E. Pong, M. Peipp and S. Karki et al., 2008. Potent in vitro and in vivo activity of an fc-engineered Anti-CD19 monoclonal antibody against lymphoma and leukemia. Cancer Res., 68: 8049-8057. DOI: 10.1158/00085472.CAN-08-2268

Hudson, P.J. and C. Souriau, 2003. Engineered antibodies. Nat. Med., 9: 129-134. DOI: 10.1038/nm0103-129

Karlsson, R., P.S. Katsamba, H. Nordin, E. Pol and D.G. Myszka, 2006. Analyzing a kinetic titration series using affinity biosensors. Anal. Biochem., 349: 136147. PMID: 16337141
Maenaka, K., P.A.V.D. Merwe, D.I. Stuart, E.Y. Jones and P. Sondermann, 2001. The human low affinity Fc $\gamma$ receptors IIa, IIb and III bind IgG with fast kinetics and distinct thermodynamic properties. J. Biol. Chem., 276: 44898-44904. DOI: 10.1074/jbc.M106819200

Natsume, A., R. Niwa and M. Satoh, 2009. Improving effector functions of antibodies for cancer treatment: Enhancing ADCC and CDC. Drug Des. Dev. Ther., 3: 7-16. PMID: 19920917

Nimmerjahn, F. and J.V. Ravetch, 2005. Divergent immunoglobulin $\mathrm{g}$ subclass activity through selective fc receptor binding. Science, 310: 15101512. DOI: 10.1126/science. 1122009

Nissim, A. and Y. Chernajovsky, 2008. Historical development of monoclonal antibody therapeutics. Therapeutic Antibodies, 181: 3-18. DOI: 10.1007/978-3-540-73259-4_1

Oganesyan, V., M.M. Damschroder, R.M. Woods, K.E. Cook and H. Wu et al., 2009. Structural Characterization of a human FC fragment engineered for extended serum half-life. Mol. Immunol., 46: 1750-1755.

Piggee, C., 2008. Therapeutic antibodies coming through the pipeline. Anal. Chem., 80: 2305-2310. DOI: 10.1021/ac086033v

Presta, L.G., R.L. Shields, A.K. Namenuk, K. Hong and Y.G. Meng, 2002. Engineering therapeutic antibodies for improved function. Biochem. Soc. Trans., 30: 487-490. DOI: 10.1042/BST0300487

Salfield, J.G., 2007. Isotype selection in antibody engineering. Nat. Biotech., 25: 1369-1372. DOI: 10.1038/nbt1207-1369

Sautes, F.C., L. Cassard, S.J. Cohen and W.H. Fridman, 2003. FC gamma receptors: A magic link with the outside world. ASHI Q. Four. Q.

Shields, R.L, A.K. Namenuk, H. Kyu, Y.G. Meng and J. Rae et al., 2001. High resolution mapping of the binding site on human IgG1 for FcyRI, Fc $\gamma$ RII, FcyRIII and FcRn and design of IgG1 variants with improved binding to the Fc $\gamma$ R. J. Biol. Chem., 276: 6591-6604. DOI: 10.1074/jbc.M009483200

Sisto, M., S. Lisi, S. D'Amore and M. D'Amore, 2009. Autoantibodies, human $\mathrm{Fc} \gamma$ receptors and autoimmunity. J. Recep. Ligand Chann. Res., 2 45-57.

Sorge, N.M.V., W.L.V.D. Pol and J.G.J.V.D. Winkel, 2003. Fc $\gamma R$ polymorphisms: Implications for function, disease susceptibility and immunotherapy. Tissue Antigens, 61: 189-202. DOI: 10.1034/j.13990039.2003.00037.x 
Stavenhagen, J.B., S. Gorlatov, N. Tuaillion, C.T. Rankin and H. Li et al., 2007. Fc optimization of therapeutic antibodies enhances their ability to kill tumor cells in vitro and controls tumor expansion in vivo via low-affinity activating $\mathrm{Fc} \gamma$ receptors. Cancer Res., 67: 8882-8890. DOI: 10.1158/00085472.CAN-07-0696

Stockwin, L.H. and S. Holmes, 2003. The role of therapeutic antibodies in drug discovery. Biochem. Soc. Trans., 31: 433-436.

Strome, S.E., E.A. Sausville and D. Mann, 2007. A mechanistic perspective of monoclonal antibodies in cancer therapy beyond target-related effects. Oncologist, 12: 1084-1095. DOI: 10.1634/theoncologist.12-9-1084
Wypych, J., M. Li, A. Guo, Z. Zhang ans T. Martinez et al., 2008. Human IgG2 antibodies display disulfidemediated structural isoforms. J. Biol. Chem., 283: 16194-16205. DOI: 10.1074/jbc.M709987200

Zalevsky, J., I.W.L Leung, S. Karki, S.Y. Chu and E.A. Zhukovsky et al., 2009. The impact of Fc engineering on an anti- $\mathrm{CD}_{19}$ antibody: Increased $\mathrm{Fc} \gamma$ receptor affinity enhances B-cell clearing in nonhuman primates. Blood, 113: 3735-3743. DOI: 10.1182/blood-2008-10-182048

Zhang, Q., G. Chen. X. Liu and Q. Qian, 2007. Monoclonal antibodies as therapeutic agents in oncology and antibody gene therapy. Cell Res., 17: 89-99. DOI: $10.1038 /$ sj.cr.7310143 